\title{
SCALING POTENTIAL OF GEOTHERMAL WATER FROM THE WELL A-2 AT VRANJSKA BANJA (SERBIA)
}

Bratislav Ž. Todorović1*, Dragan T. Stojiljković ${ }^{1}$, Tanja Petrović Pantiće, Saša R. Savić1, Sanja M. Petrović ${ }^{1}$, Nebojša Č. Mitić ${ }^{1}$, Milena S. Stojiljković ${ }^{1}$

(ORIGINAL SCIENTIFIC PAPER) UDC 550.461:626.811:628.164

${ }^{1}$ Faculty of Technology, University of Niš, Leskovac, Serbia

${ }^{2}$ Geological Survey of Serbia, Belgrade, Serbia

Geochemical and physicochemical characteristics of geothermal water from A-2 well are investigated in order to estimate its tendency towards the formation of scale in the pipe installation. Based on the geochemiocal analysis of major elements and groups, as well as triangular plots, this geothermal water can be classified as $\mathrm{Na}$ Alk·SO4 type. The ternary diagram classifies it as steamheated-peripheral water. A-2 has a good utilization capacity of $1 \mathrm{~L} \mathrm{~s}^{-1}$ at the water temperature of $84{ }^{\circ} \mathrm{C}$. Regarding this, SI values are determined as the measure of tendency to form deposits. A positive SI value of calcite (0.14) and aragonite (0.03) at the temperature of $84^{\circ} \mathrm{C}$ suggests a very low tendency to form scale, as well as the possible occurrence of a minor proportion of carbonate minerals. XRD mineralogical and SEM analyses of the scale have confirmed its calcite composition. SI values for the temperature of $25^{\circ} \mathrm{C}$ indicate the safe silicate minerals deposition due to the positive temperature coefficient. The obtained SI values indicate that the A-2 geothermal water in Vranjska Banja is suitable for use in piping installations because it shows poorly pronounced tendency to form deposits.
Keywords: Geothermal water, A-2 well, Scale, Saturation index, Calcite

\section{Introduction}

Hydrogeochemical processes in groundwater are controlled by physicochemical interactions. These interactions depend mainly on $\mathrm{pH}$ value, temperature and partial pressure of $\mathrm{CO}_{2}$. Monitoring of these parameters provide the important information on the scaling potential of geothermal water. In groundwater studies, these parameters are usually combined by saturation index (SI). SI is applied to examine the possibility of precipitation of certain minerals, for evaluating the chemical equilibrium between fluid and rock and for predicting the presence of reactive minerals, as well as estimating the mineral reactivity [1]. Also, this index can be used for estimating the reactive surface area [2]. Physicochemical parameters and concentrations of major ions need to be included to calculate SI. In order to speed up, the calculating process software program (EQ3/6 for example) is most commonly used. The use of the program reduces the cost of testing the potential formation of sediment but does not exclude the occasional practical verification of the mineralogical composition.

Vranjska Banja Spa is located in the Serbian Crystalline Core region, $12 \mathrm{~km}$ away from the town of Vranje. The oldest rocks in the wide area of Vranjska Banja Spa are from Proterozoic age (gneiss, crystalline schist and metamorphosed volcanite rocks) with Paleozoic, Mesozoic and Cretaceous-Paleogene granitoide rocks [4]. A geological map of the wide area of Vranjska Banja Spa is showed in Figure 1.

\footnotetext{
* Author address: Bratislav Todorović, Faculty of Technology, Bulevar oslobođenja 124, 16000 Leskovac, Serbia

E-mail: vinarce2001@yahoo.com

The manuscript received: February, 28, 2017.

Paper accepted: April, 04, 2017.
}

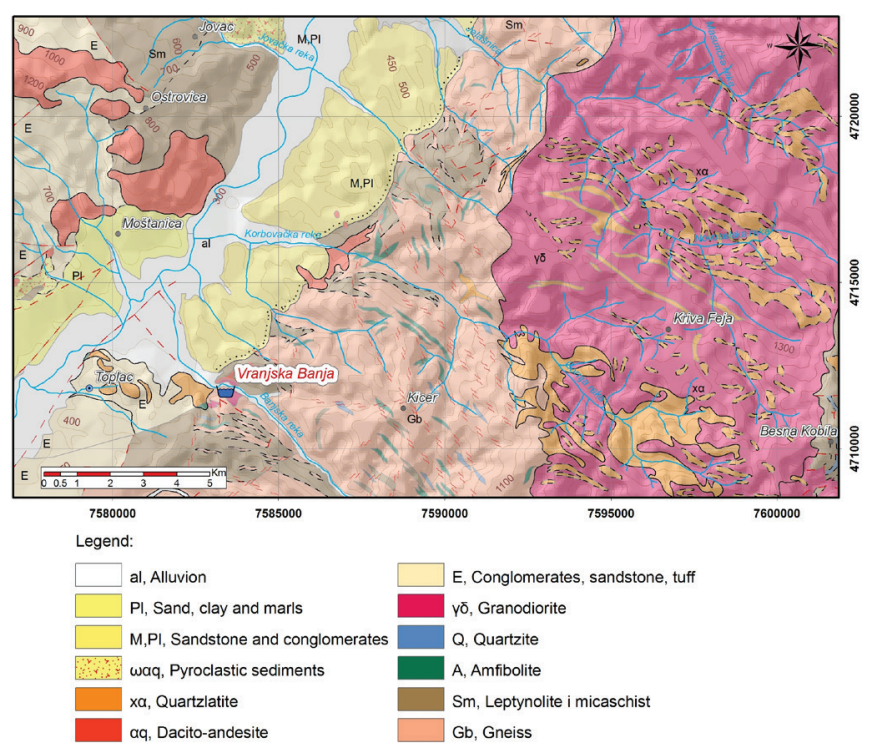

Figure 1. Geological map of the wide area of Vranjska Banja Spa ([4])

A-2 is a well with the depth of $44 \mathrm{~m}$, located near the borehole VG-3. From this well $1 \mathrm{~L}$ of water with the temperature of $84{ }^{\circ} \mathrm{C}$ is obtained. It consists of granodiorite, with occurrences of pyrite in shallow layers and amphib- 
olite shale. Today, geothermal water in the Spa Vranje is used for bathing needs, for heating the individual objects in the spa and for greenhouses and poultry farms.

\section{Experimental}

The experimental methods/techniques have already been described earlier [6]. The groundwater sample was collected in high density polyethylene bottles followed by deionized water $(0.1 \mu \mathrm{S})$ and then rinsed two to three times before sampling by using sampling water. Before the analysis, the samples were filtered by using Econofilter $0.45 \mu \mathrm{m}$ RC cellulose membrane. Field measurements of $\mathrm{pH}$ were done using a multi water quality probe (HANNA RS-232, Portugal). Electrode calibration was made by using a standard solution of HI 7071S (HANNACalibration solution).

Bicarbonate was determined with neutralization titration and chloride with the precipitation method (Mohr's Method). The gravimetric method was applied in the determination of sulphate.

Inductively Coupled Plasma-Optical Emission Spectrometry. Cations that are present in the water samples were analyzed by ICP-OES Spectro-Arcos (1.4 kW; 12 $\mathrm{MHz}$.

Scanning Electron Microscopy (SEM) works were carried out by using a Jeol JSM-35 electron microscope equipped with a Tracor TN2000 energy dispersive X-ray spectrometer. Operating conditions for the energy-dispersive analyses were $25 \mathrm{keV}$ accelerating voltage, 0.1 $\mu \mathrm{A}$ beam current and a beam spot diameter of approximately $3 \mu \mathrm{m}$.

X-ray powder diffraction (XRD) analysis. This analysis was used for the mineral identification of collected samples, using Raguku Ultima IV powder diffractometer. The X-ray beam was nickel-filtered CuKa1 radiation $(\lambda=$ $0.1540 \mathrm{~nm}$, operating at $40 \mathrm{kV}$ and $40 \mathrm{~mA}$ ). XRD data were collected from 5 to $90^{\circ}(2 \theta)$ in a continuous scan mode with a scanning step size of $0.02^{\circ}$ and at a scan rate of $5^{\circ} \mathrm{min}^{-1}$. The phase analysis, accompanied with Rietveld refinement, was done by using the PDXL2 software (version 2.0.3.0).

Total uncertainty (including accuracy error) of the analysis is less than $5 \%$.

\section{Results and discussion}

Geochemical and physicochemical characteristic of

A-2 geothermal water

$\mathrm{Na}^{+}$and $\mathrm{HCO}_{3}^{-}$represent the dominant ions (880 and $380 \mathrm{mg} \mathrm{L}^{-1}$; Table 1). Cations concentrations that are present in the water samples decreases in the following order $\mathrm{Na}^{+}>\mathrm{Ca}^{2+}>\mathrm{Al}^{3+}>\mathrm{Mg}^{2+}>\mathrm{Sr}^{2+}>\mathrm{Fe}^{2+} / \mathrm{Fe}^{3+}$ and anions: $\mathrm{HCO}_{3}^{-}>\mathrm{SO}_{4}^{2-}>\mathrm{Cl}^{-}$. At pH value of 7.4 , dissolved carbonates occur predominantly in the form of $\mathrm{HCO}_{3}^{-}$ion. According to temperature, total hardness and $\mathrm{pH}$, this water belongs to hyperthermal, very soft and moderately alkaline (Table 1.).
Table 1. Concentration of major ions in A-2 geothermal water [mg L $\left.\mathrm{L}^{-1}\right]$ and its physicochemical parameters.

\begin{tabular}{|c|c|c|c|}
\hline \multicolumn{2}{|c|}{ IONS } & \multicolumn{2}{|c|}{ PARAMETERS } \\
\hline $\mathrm{Na}^{+}$ & 880 & $\mathrm{~T}\left[{ }^{\circ} \mathrm{C}\right]$ & 84.0 \\
\hline $\mathrm{K}^{+}$ & 10 & $\mathrm{pH}$ & 7.4 \\
\hline $\mathbf{M g}^{2+}$ & 1 & pHs & 7.0 \\
\hline $\mathrm{Ca}^{2+}$ & 15 & L.S.I. & 0.4 \\
\hline $\mathbf{A l}^{3+}$ & 1 & R.S.I. & 6.6 \\
\hline $\mathrm{Fe}^{3+} / \mathrm{Fe}^{2+}$ & $<0.01$ & Total hardness $\left[{ }^{\circ} \mathrm{dH}\right]$ & 2.3 \\
\hline $\mathrm{Si}^{*}$ & 15 & Dry residue $\left[\mathrm{g} \mathrm{L}^{-1}\right]$ & 1.8 \\
\hline $\mathrm{HCO}_{3}^{-}$ & 380 & Conductivity[S cm$\left.{ }^{-1}\right]$ & 1.4 \\
\hline $\mathrm{Cl}^{-}$ & 55 & & \\
\hline $\mathrm{SO}_{4}^{2-}$ & 365 & & \\
\hline
\end{tabular}
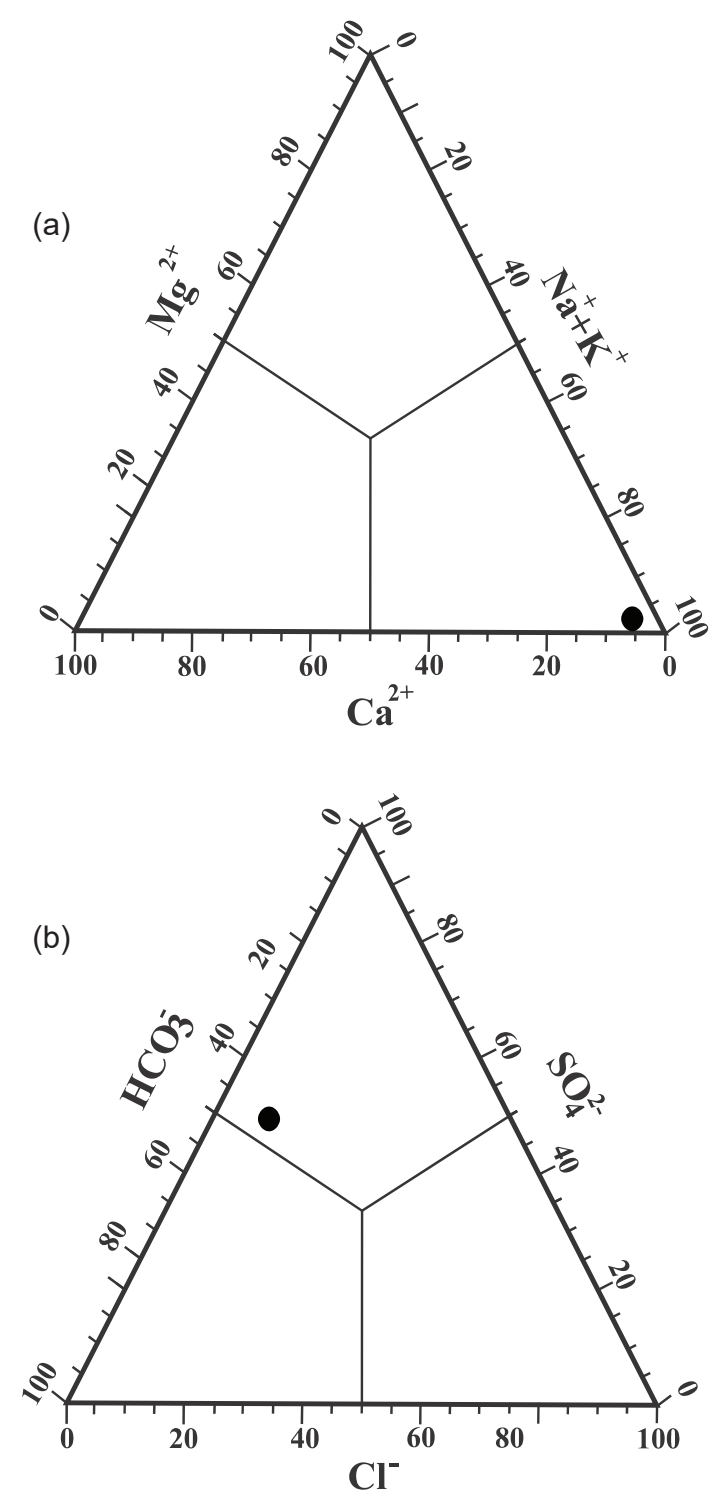

Figure 2. Triangular plots of: a) $\mathrm{Ca}^{2+}-\mathrm{Mg}^{2+}-\left(\mathrm{Na}^{+}+\mathrm{K}^{+}\right)$and b) $\mathrm{HCO}_{3}^{-}-\mathrm{SO}_{4}^{2-}-\mathrm{Cl}^{-}$for $\mathrm{A}-2$ geothermal water

The concentrations of major cations $\left(\mathrm{Na}^{+}, \mathrm{Ca}^{2+}, \mathrm{K}^{+}\right.$, $\mathrm{Mg}^{2+}$ ) and anions in $\mathrm{mg} \mathrm{L}^{-1}$ were plotted in the triangualare plots (Figure 2 ) to evaluate the hydrochemistry 
of geothermal water. Plots show the relations of different hydrochemical variables which are relevant for the hydrochemical evolution and the groundwater flow dynamics. Geothermal waters from Vranjska Banja can be classified as of Na-Alk·SO4 type. Based on the ternary diagram, this water is classified as steamheated-peripheral water (Figure 3). This classification is consistent with the classification of VG-2 and VG-3 geothermal water in Vranjska Banja [7].

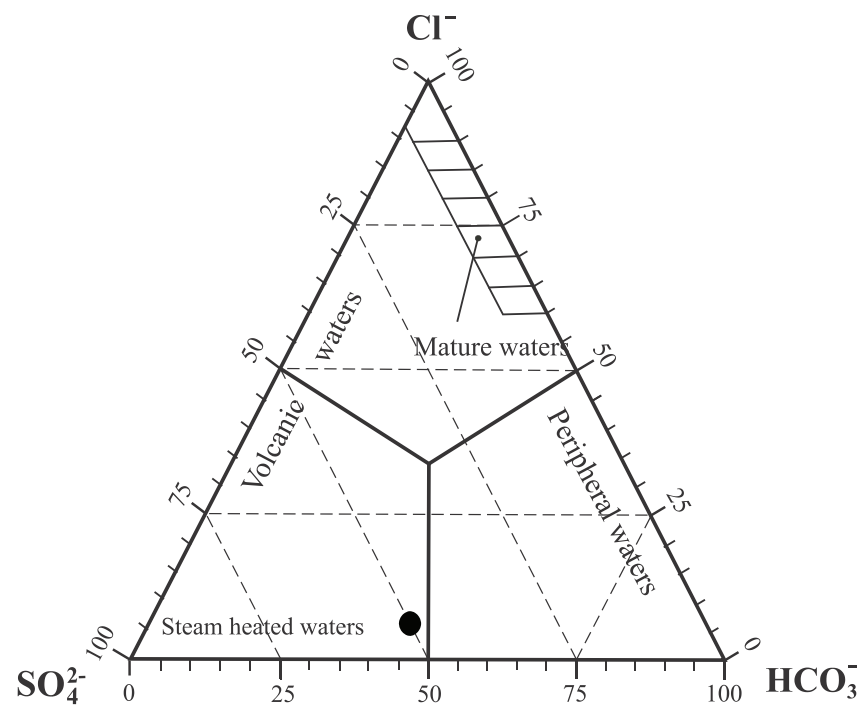

Figure 3. $\mathrm{Cl}^{-}-\mathrm{SO}_{4}^{2-}-\mathrm{HCO}_{3}^{-}$ternary plot for $\mathrm{A}-2$ geothermal water (based on [8])

Table 2. SI of carbonate and evaporate minerals in the A-2 geothermal water at the temperature of $84^{\circ} \mathrm{C}$ and $25^{\circ} \mathrm{C}$

\begin{tabular}{lrc}
\hline \multicolumn{1}{c}{ Mineral } & \multicolumn{2}{c}{ Temperature } \\
& $84{ }^{\circ} \mathrm{C}$ & $25{ }^{\circ} \mathrm{C}$ \\
\hline Albite & -1.96 & 1.20 \\
Alunite & -6.79 & 2.30 \\
Anhydrite & -1.60 & -2.25 \\
Anorthite & -1.77 & -0.29 \\
Aragonite & 0.03 & -0.69 \\
Ca-Montmorillonite & -1.22 & 5.88 \\
Calcite & 0.14 & -0.54 \\
Chalcedony & -0.63 & -0.05 \\
Chlorite & -0.02 & -7.43 \\
Chrysolite & -3.64 & -9.26 \\
Dolomite & -0.64 & -1.93 \\
Gypsum & -1.88 & -1.95 \\
Halite & -6.00 & -5.94 \\
Illite & -1.67 & -5.02 \\
K-feldspar & -2.17 & 1.59 \\
Kaolinite & 1.09 & 6.87 \\
Quartz & -0.35 & 0.38 \\
Sepiolite & -9.73 & -9.37 \\
SiO2 & -1.30 & -0.89 \\
Talc & -0.59 & -5.66
\end{tabular}

Scaling

Langelier's Saturation Index (LSI) value of 0.4 indicates a slight tendency towards corrosion but not to- wards scaling. This assumption is confirmed by its Ryznar's Stability Index (RSI) value of 6.6 (Table 1), based on interpretations of Ryznar [9]. Newer interpretation of RSI values based on Carrier, 1965, indicates the possibility of litle scale. In order to clarify these concerns, the determination is done by using the SI index EQ 3/6 software program based on the concentration of present ions. By using SI index EQ 3/6 program, the ionic activity $Q$ corresponding to different minerals in the brine was calculated and it was compared with the theoretical solubility, $\mathrm{K}$, of the respective minerals. When $\mathrm{Q}<\mathrm{K}$, the saturation index is negative and the solution is undersaturated with respect to the mineral considered. When $\mathrm{Q}>\mathrm{K}$, the solution is supersaturated and when $\mathrm{Q}=\mathrm{K}$, the solution is exactly saturated or in equilibrium with the mineral in respect. Based on the values of $Q$ and $K$, the obtained $\mathrm{SI}$ is calculated by the following equation: $\mathrm{SI}=$ Q $\log -\log \mathrm{K}$. SI of A-2 was calculated for carbonate and evaporates minerals (Table 2).

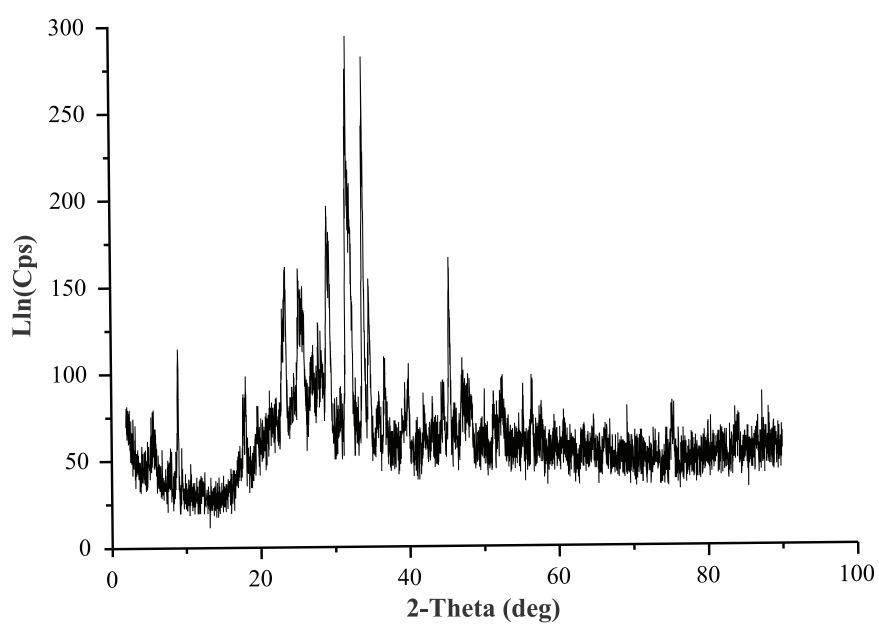

Figure 4. XRD spectrum of calcite from geothermal water A-2

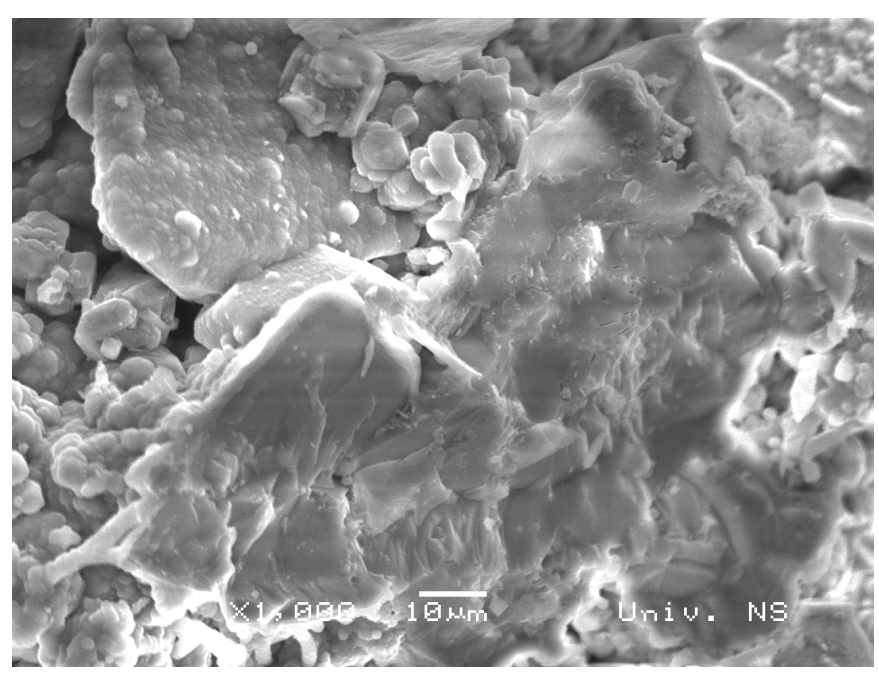

Figure 5. SEM of sediment formed by deposition of A-2 water in pipe installations

Based on Table 2, SI values of calcite and aragonite have low positive values indicating the possible occurrence of small amounts of carbonate minerals. Indeed, 
in the multi-year inflow of a A-2 water in Banjska Reka at the flow rate of $1 \mathrm{~L} \mathrm{~s}^{-1}$, the output tubes result in the formation of minor amounts of scale (<100 g; Figure 4). Figure 4 shows XRD data analysis that confirms the scale $\mathrm{SI}$ assumptions for minor amounts of calcite occurrence in pipe installations at the temperature of $84^{\circ} \mathrm{C}$. Calcite scale SEM is shown in Figure 5.

Silica scaling is probably the most troublesome scaling encountered in geothermal systems due to its stiff crystalline structure. Silica scaling is mainly dependent on $\mathrm{pH}$, temperature and silica concentration. Silica scaling will occur only when $\mathrm{SI}$ is greater than 1 , even to 1.4 , depending on the temperature [10]. Compared to the carbonates that have a negative temperature coefficient of solubility of $\mathrm{CaCO}_{3}$ in water, the coefficient solubility of silicate is positive [11-13]. Therefore, carbonates are formed on a higher and silicate at a lower temperature of the geothermal water. With the decrease of the water temperature to $25^{\circ} \mathrm{C}$, scaling silicate minerals (Table 2) are expected with $\mathrm{SI}$ values higher than 1.4. Of course, such a scenario would be carried out in case that geothermal water A-2 is practically used for industrial and energy purposes rather than freely flowing into Banjska Reka.

\section{Conclusion}

In this paper, geochemical and physicochemical characteristics of geothermal water A-2 are investigated in order to determine its tendency towards the formation of scale in the pipe installation. Based on the analysis of major elements and groups, as well as triangular plots, this geothermal water can be classified as Na-Alk.SO4 type. Based on the ternary diagram, it is classified as steamheated-peripheral water.

The calculated SI values at the temperature of $84{ }^{\circ} \mathrm{C}$ indicate the occurrence of a minor scale in the form of carbonates (mainly calcite). These data were confirmed by XRD analysis of practical scale. SI data obtained for teh temperature of $25{ }^{\circ} \mathrm{C}$ indicate the deposition of a number of different silicate minerals. Obtained SI, LSI and $\mathrm{RSI}$ values indicate that the A-2 geothermal water in Vranjska Banja is good to use for pipes in the installations because it shows a low tendency to form deposits.

\section{Acknowledgements}

This work was supported by the Ministry of Education, Science and Technological Development of the Republic of Serbia under Projects No. TR 33034.

\section{References}

[1] W. J. Deutsch, Groundwater Geochemistry: Fundamentals and Applications to contamination, 1997, Lewis, USA.

[2] L. Marini, G. Ottonello, M. Canepa, F. Cipolli, Water-rock interaction in the Bisagno valley (Genoa, Italy): Application of an inverse approach to model spring water chemistry,
Geochimica et Cosmochimica Acta 64(15) (2000) 26172635.

[3] T. W. Wolery, R. L. Jarek (2003) Software user's manual. EQ3/6, Version 8.0. Sandia National Laboratories-U.S. Dept. of Energy Report.

[4] M. Babović, Č. Roglić, V. Avramović, S. Marić, Explanatory Booklet of the Basic Geological Map of the SFR Yugoslavia, Sheet Trgovište with Radomir K 34-57, Savezni geološki zavod, Belgrade, 1977, p. 58.

[5] T. Petrović Pantić, Hydrogeothermal resources of Serbian crystalline core. Thesis, University of Belgrade, 2014.

[6] B. Ž. Todorović, D. T. Stojiljković, T. Petrović Pantić, N. Č. Mitić, Lj. S. Nikolić, S. M. Cakić, Hydrogeochemistry and aragonite scaling in the Sijarinska Spa (Serbia), Carbonates and Evaporites, 31(4) (2016) 367-374.

[7] T. Petrović Pantić, M. Birke, B. Petrović, J. Nikolov, V. Dragišić, V. Živanović, Hydrogeochemistry of thermal groundwaters in the Serbian crystalline core region, Journal of Geochemical Exploration, 159 (2015) 101-114.

[8] W. F. Giggenbach, Geothermal solute equilibria. Derivation of Na-K-Mg-Ca geoindicators. Geochimlca et Cosmochimica Acta, 52 (1988) 2749-2765.

[9] J. N. Ryznar, A new index for determining amount of calcium carbonate scale formed by a water, Journal of American water works Association, 36 (1944) 472-478.

[10] K. Brown, Thermodynamics and Kinetics of Silica Scaling, Proceedings from the International Workshop on Mineral Scaling, 2011, Manila, p. 1.

[11] R. M Garrels, C. L. Christ, Solutions, minerals, and equilibria, Harper and Row, New York, 1965.

[12] S. Arnórsson, Deposition of calcium carbonate minerals from geothermal waters-theoretical considerations, Geothermics, 18 (1989) 33-39.

[13] D. Langmuir. Aqueous Environmental Geochemistry, Prentice-Hall, Englewood Cliffs, New Jersey, 1997. 
Izvod

\section{SKLONOST KA STVARANJU KAMENCA GEOTERMALNE VODE IZ BUNARA A-2 SA LOKALITETA VRANJSKA BANJA (SRBIJA)}

Bratislav Ž. Todorović ${ }^{1}$, Dragan T. Stojiljković ${ }^{1}$, Tanja Petrović Pantić2 ${ }^{2}$ Saša R. Savić ${ }^{1}$, Sanja M. Petrović ${ }^{1}$, Nebojša Č. Mitić ${ }^{1}$, Milena S. Stojiljković ${ }^{1}$

${ }^{1}$ Tehnološki fakultet, Univerzitet u Nišu, Leskovac, Srbija

$2_{\text {Geološki zavod Srbije, Beograd, Srbija }}$

Proučavane su geohemijske i fizičko-hemijske karakteristike geotermalne vode iz bunara A-2 u cilju procene njene sklonosti stvaranju kamenca u cevnim instalacijama. Na osnovu geohemijske analize glavnih elemenata i grupa, kao i na osnovu trougaonih dijagrama ova geotermalna voda se može klasifikovati kao $\mathrm{Na}-\mathrm{Alk} \cdot \mathrm{SO} 4$ tip, dok se na osnovu termalnog dijagrama klasifikuje kao pregrejana vodena para. A-2 poseduje dobar kapacitet iskorišćenosti od $1 \mathrm{~L} \mathrm{~s}^{-1}$ na temperaturi vode od $84^{\circ} \mathrm{C}$. Pri ovim uslovima, SI vrednosti se određuju kao mera sklonosti ka stvaranju kamenca. Pozitivne SI vrednosti kalcita $(0,14)$ i aragonita $(0,03)$ na temperaturi od $84^{\circ} \mathrm{C}$ ukazuju na veoma nisku tendenciju ka stvaranju kamenca, kao i na mogućnost pojave manjih količina ovih karbonatnih minerala na cevnim instalacijama. XRD analiza sastava kamenca potvrdila je pretpostavku o nastanku kalcita. SI vrednosti za temperaturu od $25^{\circ} \mathrm{C}$ ukazuju na nastanak silikatnih minerala zbog pozitivnog temperaturnog koeficijenta. Dobijene SI vrednosti ukazuju da je A-2 geotermalna voda pogodna za upotrebu u cevnim instalacijama jer pokazuje slabo izraženu tendenciju ka stvaranju kamenca.
Ključne reči: Geotermalna voda, A-2 bunar, Kamenac, Saturacioni indeks, Kalcit 